\title{
Research on the Optimization of Oral English Teaching in Junior High School in the Environment of Man-machine Dialogue*
}

\author{
Jiani Yao \\ Foreign Language College, Zhejiang Ocean University, Zhoushan, China \\ Fusheng Zhang \\ Foreign Language College, Zhejiang Ocean University, Zhoushan, China \\ Hongying Li \\ Foreign Language College, Zhejiang Ocean University, Zhoushan, China
}

\begin{abstract}
Dumb English is a serious phenomenon among most teenagers in China. When the assessment system of man-machine dialogue is added to the entrance examination, English listening and speaking ability becomes indispensable to students. How to arouse teenagers' interest in spoken English and effectively improve their listening and speaking ability is very critical. The main learning environment for students is the classroom, hence classroom teaching plays a key role in enriching students' ability of listening and speaking. In view of the problems existing in junior high school classroom and students' listening and speaking ability, the relevant optimization strategies are presented.
\end{abstract}

Index Terms — man-machine dialogue, oral practice, listening and speaking ability

\section{INTRODUCTION}

In the course of deepening the reform of teaching curriculum in our country, in order to effectively improve the speaking and listening ability of junior high school students and promote the quality of English teaching, many regions of the country have begun to incorporate the mode of man-machine dialogue into the entrance examination of English, for instance, the class of 2015 at junior high school in Jiaxing District of Zhejiang Province have taken the lead in carrying out man-machine dialogue mode in English of the entrance examination. The emergence of the new evaluation system of "man-machine dialogue" has broken the previous teaching approaches. It requires teachers to pay attention not only to the training of written examination, but also to the training of students' oral expression and listening ability. Experts and scholars have done a lot of research on English listening and speaking. However, in recent years, with the development of network information technology, man-machine dialogue as a new form of examination to test students' listening and speaking ability has improved the status of oral English in the examination, breaking the tendency of teachers' traditional teaching focus. At present, there are few studies on English classroom teaching under the "man-machine dialogue" environment. We know that language acquisition is closely related to the environment, and a good language environment can promote students' language learning. Classroom is an important place for students to learn language. To explore how to optimize junior high school English classroom through scientific methods in order to better adapt to the new evaluation environment of "man-machine dialogue". To make effective suggestions for teachers to innovate their own classroom teaching and create a favorable language interaction environment, so that teachers can improve students' listening and speaking skills in the teaching process and thus improve the quality of English teaching.

\section{ORAL ENGLISH TEACHING AND ReLATIVE THEORIES}

\section{A. Oral English Teaching}

English is a compulsory course in basic education, while Oral English is an important basic skill of English. The basic goal of oral English teaching is to cultivate students' oral communicative competence. Scholars home and abroad have also made in-depth studies on it. Chen Ning (2009), a Chinese scholar, pointed out that oral English teaching is different from the general knowledge imparting process. Its teaching mode needs to embody more about the practicability, knowledge and interest of English teaching, which is conducive to arousing the enthusiasm of both teachers and students, especially the students' principal position in the teaching process and the teachers' leading role in the teaching process. Situational teaching also plays an important role in oral English teaching (Jin, 2017).

\footnotetext{
${ }^{*}$ The article is the fruit of the project 'Research on the construction and application of English micro-course learning resource base under the background of Internet + ' from the Department of Education of Zhejiang Province, China.
} 


\section{B. Man-machine Dialogue}

Man-machine dialogue is a kind of test form which implements and manages examination by means of computer and network technology. According to the requirements of examination design, it can make proposals and compose papers pertinently, and complete a series of links such as question presentation, answer acceptance, scoring, data analysis and result interpretation.

Presently, the type of questions in man-machine dialogue in the senior high school entrance examination contains listening to short dialogues and choosing answers in the first section, listening to long dialogues and choosing answers in the second section, reading text in the third section, listening to dialogues or monologues and answering questions in the fourth section, and expressing topics in the fifth section.

\section{The Relation between Man-machine Dialogue and Oral English Teaching}

Man-machine dialogue is closely related to the oral English teaching. Man-machine dialogue is a good way to test oral English teaching. Man-machine dialogue combines listening and speaking tests into one (Yu, 2018). With the development of automation of oral English test, man-machine dialogue has made the traditional oral English test out of the stage (Mei, 2012). How to make students adapt to this new oral English test mode is very important.

\section{ReSEARCh on Oral English Teaching UndeR the MAN-MACHINE DialoguE}

\section{A. Participants}

We randomly selected 200 students from Grade 7 to Grade 9 in Zhoushan and Jiaxing, Zhejiang Province to finish the questionnaire. The average age of the students is about 15 years old. They come from different schools and classes. This makes the data universal. The interviewees are junior high school English teachers. They are experienced teachers who have been teaching for many years.

\section{B. Research Methods}

\section{Questionnaire}

Through questionnaires, junior high school students are asked to self-evaluate their oral proficiency, so as to understand a basic situation of junior high school students' oral proficiency. In addition, a questionnaire was conducted to investigate their needs for spoken English, what kind of English classes they think of, and what level they want to achieve in spoken English.

Such a survey will enable us to have a deep understanding of the current students' oral proficiency, their aspirations and their acceptance of this new model from the perspective of students.

2. Class Observation

Through a two-week educational internship, we observed English classroom teaching in Zhoushan Nanhai Experimental Middle School and Zhoushan First Junior Middle School. It mainly observes teachers' classroom teaching methods, focusing on teachers' penetration of spoken English in the daily classroom. Observe some oral activities organized by teachers in class, and observe students' participation and enthusiasm.

Through this method, we can intuitively understand the real classroom language environment, and know the teaching methods and activities of teachers, so that we can have a basic understanding of oral English teaching and students' performance in the classroom.

3. Interview

Based on the questionnaire and the classroom observation, I interviewed the junior high school English teachers in Zhoushan where is going to take man-machine dialogue and the teachers in Jiaxing where has taken the man-machine dialogue test. Six teachers were interviewed. Mainly inquired about the teacher's views on the new evaluation model of man-machine dialogue, which was added to the entrance examination; the way the teacher's junior high school adopted to cope with it; whether man-machine dialogue had a great impact on teachers, whether there were great changes in the preparation of lessons and teaching methods; how teachers would promote students' listening and speaking ability; and the difficulties in oral English teaching and teachers' use of Chinese in the present teaching process.

\section{RESUlts AND DiscusSiON ON ORAL ENGLiSH TEACHING UNDER THE MAN-MACHINE DiALOGUE RESEARCH}

Based on the data obtained from the questionnaire, classroom observation and interview, we get the following results, and discuss and analyze the existing problems.

\section{A. Result}

1. Results for the Questionnaire

We have distributed 200 questionnaires to junior high school students from grade 7 to grade 9 . Through the data, we have the following findings:

In the survey, we asked students to make self-evaluation of their oral proficiency. The result is that almost no students think that their oral English expression ability has reached an excellent level. Most students hold the view that their oral proficiency is within the range of passing to good, which does not exclude subjective factors. Therefore, we choose 
different students to communicate in English in order to further test their spoken English. Obviously, the results are not satisfactory. Most of the students' oral proficiency is exactly what they have evaluated.

After that, we make a further investigation on whether the students want to improve their spoken English, to what extent they want to improve their spoken English and the reasons. About $83.4 \%$ of the students surveyed want to improve their oral English, but the ones who don't want to improve theirs also take up certain proportion. This may be related to students' subjective thinking.

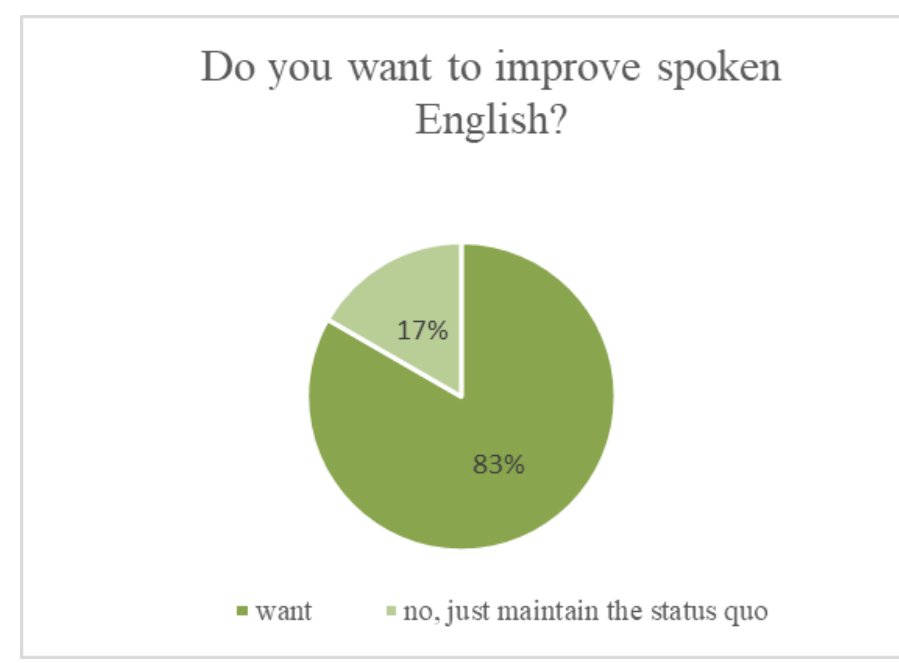

Among the students who want to improve their oral proficiency, we also conducted a questionnaire survey on the oral proficiency they want to achieve. A small number of students feel that they can have a simple dialogue, but the vast majority of students hope that they can speak English fluently. When asked why they wanted to improve their spoken English, we got multiple answers. Some people are for the needs of examinations; some people are for their own love of spoken English; some want to go abroad; and some want to make international friends and other reasons. However, $66.67 \%$ of the students need to improve their spoken English for their examination. It shows that most of the students improve their spoken English firstly because of the needs of the current examination.

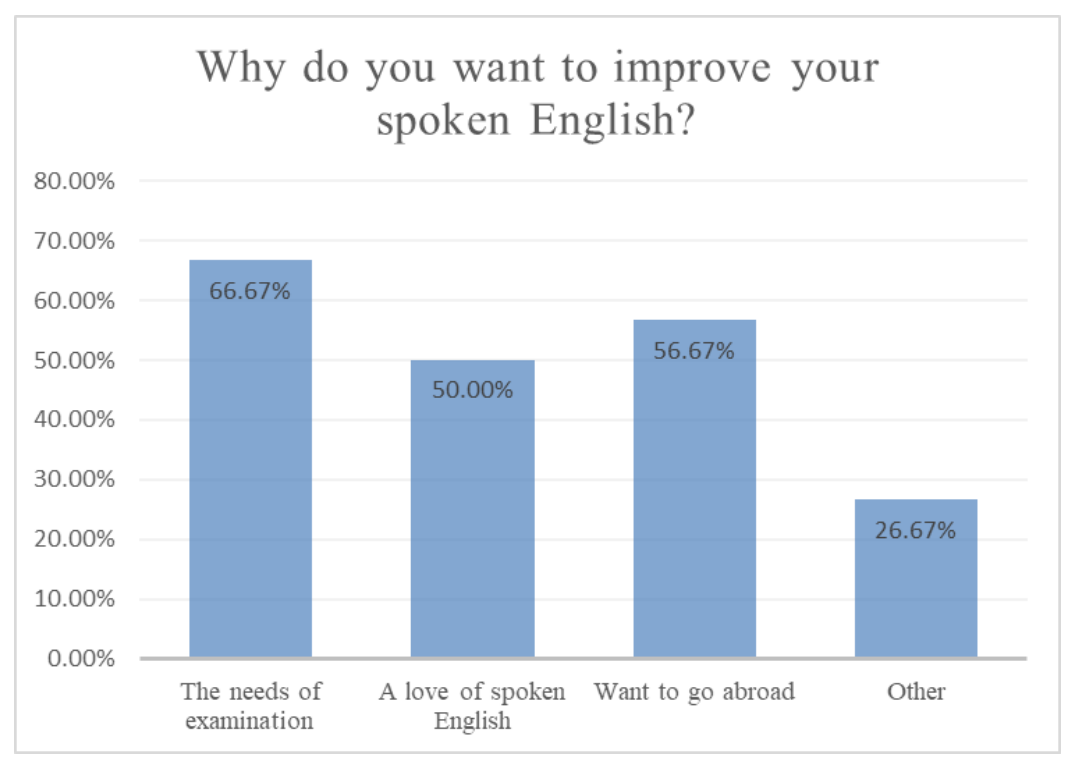

Additionally, in our questionnaire survey, about $16 \%$ of the students can consciously carry out oral training in daily life, while $33.33 \%$ of the students said that they do not complete oral training in daily life. $50 \%$ of the students said that under the supervision of teachers, for example, teachers assign oral homework, then they will carry out oral drill. This shows that although the students have the awareness of improving spoken English, but lack of action.

In the questionnaire, when we ask about the teaching methods of teachers, we find that the current junior high school English classroom is a way of mixing Chinese and English, and the most acceptable way for students is like this. Students also said that they preferred a variety of ways of training spoken English in class. For example, practicing dialogue in group, role-playing, etc. 


\section{How do you want teachers to train oral English in class?}

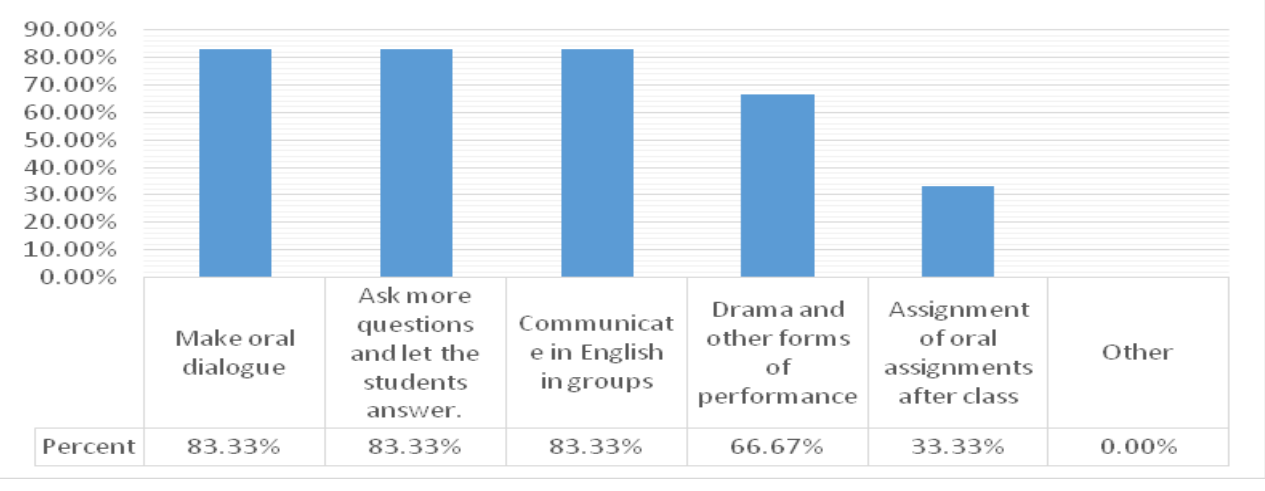

2. Results for Interview

On the basis of questionnaires, we also interviewed the relevant teachers. Most of the teachers said that man-machine dialogue is a more scientific way. It will also make teachers and students pay more attention to the cultivation of oral English ability. It will enable students to learn English comprehensively. It is both an opportunity and a greater challenge for students. Teachers said that they have added more oral activities in the classroom, so that students can exercise their oral English as much as possible. Teachers will use simple English vocabulary and sentences to ask questions and guide students to answer.

Some teachers said that in the man-machine dialogue test system, the first two parts are similar to the previous examination. They mainly test the students' listening ability. It's just a way of answering questions from the original paper to the computer. But from the third part, they mainly test the students' oral ability. From chapter reading to asking and answering, and topic expression, the examination is very comprehensive, basically covering the main form of spoken language and most teachers said that the form of the fifth question is equivalent to making an oral essay on the spot. Students with weak English ability basically can not open their mouths to finish the fifth question, and they do not know how to express it at all. Therefore, it is necessary to exercise students in the usual classroom. The listening, speaking, reading and writing of English are complementary to each other.

In short, in our survey, we found that some students have weak oral foundation, poor self-control and low motivation. We also found that teachers may neglect the cultivation of students' interest in oral English.

\section{B. Results Analysis}

According to the problems we found in the junior high school classroom and the students' learning of English, especially in oral English, we have made the following explorations:

1. Neglect of Oral English Ability

Teachers neglect the cultivation of oral competence in the process of teaching. In the English syllabus, the teaching objectives are clear, but there are some deviations in the actual implementation of teaching (Xu, 2017). Entrance examination can be said to be a vane of teaching. Since the oral proficiency test is not included in the entrance examination earlier, most students and teachers will ignore the training of oral proficiency, usually focusing on the training of written English test ability. And for a long time, when teachers teach in class, they often use their mother tongue for in-depth explanation. We know that language atmosphere is very significant for language learning, so it is bound to have a certain impact on students. Teachers' ability to implement Communicative Language Teaching (CLT) affects the students' communicative competence (Irawan, 2019). According to the questionnaires and interviews with a number of ordinary teachers and researchers, we know that in the current English classroom teaching in secondary schools, teachers mainly teach in English, supplemented by Chinese tips (but not in rural junior high schools). Among the students surveyed, $90 \%$ of them said they were mostly receptive to semi-Chinese and semi-English teaching methods. It shows that in the subconscious of students, they still rely on their mother tongue. There are some shortcomings in the students' English level which leads to the fact that they have not adapted themselves to the whole English environment.

In addition, due to the large number of students in a middle school class, teachers can not take into account each student, and further guide each student to pronounce accurately, which also leads to the overlook of students' oral expression ability.

2. Neglect of Interest in Spoken English

Teachers neglect the cultivation of students' interest in oral English in teaching. Interest is the best teacher. But because of the need of entrance examination, most teachers tend to "exam-oriented education". In the process of teaching, teachers only pay attention to students' achievements and neglect students' interests. Under the examination-oriented education system, the teaching task is comparatively tough and the teaching plan is compact. 
Teachers must grasp the tempo of the classroom well and they want to let students learn new lessons in the classroom and master the knowledge of learning well. This makes most teachers neglect some activities that can stimulate students' interest in teaching. Most teachers tend to go straight to the theme in the class and carry out the traditional teaching mode of "the explanation of words, grammar and text ". But interest plays an important role in language learning. We know that language learning is not accomplished overnight, and it is a gradual process. Teaching is also flexible, but not copying materials. Teaching should be adapted according to the circumstance. In the course of our visit, we found a common phenomenon that when teachers ask questions, few or no one answers them. On the one hand, students are shy and dare not answer. On the one hand, students are not interested in teachers' problems, leading that students do not want to think deeply. This leads to the consequence that students speak less or even no English in class.

In secondary school, students' interest in English learning will be weakened due to the increasing difficulty of vocabulary and grammar, hence teachers should start from students' interests and care about students.

3. Students' Poor Oral English Ability

Students have poor oral English ability. Our survey found that most students' oral ability is weak. In this regard, we conducted a further investigation and found that the main reason for the students' weak oral expression ability is the long-term silence. As a foreign language, the acceptance of English varies from person to person, but language proficiency and fluency are inseparable from practice. Therefore, if you want to speak English fluently, you must practice constantly. For a long time, the examination-oriented education has not involved oral English, which causes most students to emphasize written practice and neglect oral expression. If things go on like this, students are relatively unfamiliar with "speaking English", do not know how to open their mouth, and some students are afraid that their poor English will be laughed at by their peers, so they dare not speak. We know that middle school students have a strong sense of self-esteem. Being laughed at by their peers will frustrate their self-confidence, thus they dare not speak it out. Students have psychological barriers when expressing (Chen, 2019).

Although opening the mouth to speak English is very important, correctness is also very essential. We know that in the junior high school class, the large number of students limit their performance in oral practice. In this case, teachers mostly do some oral training by letting peer dialogue or other forms. But this kind of training is not sufficient, students mainly practice spoken English after class. The majority of students train oral English by themselves, or dialogue with their classmates to practise. These methods have some validity, but it cannot achieve accuracy. Because the level of junior high school students is comparatively limited, it is difficult to find out their problems in time. For example, some students can't realize the problems of pronunciation and intonation.

\section{Students' Poor Self-discipline}

Students have poor self-discipline and enthusiasm under the awareness of improving spoken English. Although the students' oral expression ability is not strong, they still want to improve their oral English ability. In our survey, it is also found that students want to improve their spoken English first because of the need of examinations. Most of the students still pay more attention to the test scores. And they have the idea that learning is for the test. Before, there was no real oral proficiency test, so students did not realize the importance of oral English at the beginning, but after man-machine dialogue was added to the entrance examination, it was related to students' entrance to school. Students enhance their awareness of oral English.

In addition, we also know that students' self-control ability is not very strong, especially junior high school students, they are in a critical period of physical and mental development, and most middle school students will have rebellious behavior at this stage, so in this period, most junior high school students' self-control ability is not strong. In oral English training, they do not pay attention to the usual training. According to the survey, only about $25 \%$ of the students in a junior high school class completed the assignment of the teacher's oral English homework during the winter vacation. This shows that although the students want to improve the awareness of spoken English, but lack of action. Moreover, during the junior high school classroom listening, we also found that the students did not show very positive response to the teacher's questioning.

To sum up, in today's society, since oral English has not been included in the scope of entrance examination in the earlier, most students and teachers will ignore the cultivation of oral English ability, usually focusing on the training of written English test ability. Meanwhile, most middle school students pay no heed to the regular training because of lack of capability and self-discipline ability. Over time, the phenomenon of "dumb English" among middle school students is becoming more and more serious. The emergence of the new evaluation system of "man-machine dialogue" undoubtedly places spoken language in a significant position, making the public aware of the importance of spoken language, so as to promote people to improve their listening and speaking ability.

\section{Limitation and Suggestions on Oral English Teaching}

\section{Limitation of Current Oral English Teaching}

From the analysis of the results, we can find that there are big problems in junior high school students' speaking. On the one hand, students' speaking ability is weak, they dare not speak, and they are afraid to speak. Students have poor self-control, lack of action ability and low enthusiasm. On the other hand, there are some shortcomings in oral English teaching in classroom. For example, due to the long-term examination-oriented education, teachers do not attach much importance to oral English and neglect the cultivation of students' interest and ability in oral English. This leads to the dilemma of oral English teaching at present. Dumb English is very serious in junior high school. Faced with the new 
evaluation method of man-machine dialogue, teachers and students are under great pressure.

2. Suggestions on Optimizing Classroom Oral English Teaching

Aiming at the problems found in the investigation and analysis of our results, we put forward the following methods to optimize oral English teaching in junior high school in terms of the problems existing in oral English teaching and students' needs for oral English:

1) Changing the traditional mode of thinking and using various teaching methods flexibly. On the one hand, from the viewpoint of most teachers and students, it is unavoidable to have the idea of paying attention to the training of written language while neglecting the training of oral expression. Because in the middle school entrance exams over the years, the scoring of English is only on the paper, and there is no link to test oral English ability. Now the evaluation model of "man-machine dialogue" is attached to the middle school entrance examination, which is certainly a reminder to everyone. Oral English is also very crucial for English learning. Therefore, teachers should pay much more attention to the training of oral English ability in classroom teaching. Not only the methods of training students are focused on, but also to innovate their own ideas and conform to the trend of the times. Students should also be aware of the importance of oral expression ability and take the initiative to seek opportunities to practice their listening and speaking ability.

On the other hand, teachers should learn to use various teaching methods flexibly. In the teaching, teachers can combine situational teaching method and task-based teaching method. Teachers can create certain situations in the classroom according to the teaching objectives of the current class, and tailor some activities for students, so that students can constantly practise their listening and speaking ability in the process of completing these activities, and stimulate their interest in learning and let them form good habits of learning. For example, in the course of "I'm more outgoing than my sister" in PEP eighth-grade, this lesson mainly talks about comparative grade and involves some new words, while the grade 8 students have accumulated some vocabulary. Teachers can create certain situations in the class. First, teachers can give examples, and then let students compare their height, age and character, so as to stimulate their interest in learning and let them express it in English. After that, let students make a brief self-report in English in groups.

2) Educating students in accordance with their aptitude and improve their listening and speaking abilities step by step. It is clear that the improvement of students' abilities on listening and speaking can not be achieved easily, while it needs a long-time effort. It involves students' vocabulary and vocabulary proficiency, as well as their basic language knowledge, reading ability, pronunciation accomplishment and thinking ability (Wang, 2018). The pronunciation of English words has its regularity and can be followed. Therefore, teachers should let students learn how to pronounce correctly step by step. Therefore, in the Grade seven of junior middle school, we should focus on phonetic symbols, let students master the pronunciation rules of letters combination, involve natural spelling into the spelling rules, and integrate games, English songs into the pronunciation teaching so as to lay a good foundation for students. Stimulate their interest in learning, and make adequate preparations for their further study. Secondly, teachers should take every student into account in the classroom. Although there are many students in each class, teachers can ask some students to answer randomly so that each student has the opportunity to answer and show themselves. Teachers should adopt different teaching methods for different students (Chen, 2016).

3) Increasing the English language atmosphere in the classroom. We know that the influence of environment on a person is imperceptible, especially young students, who are immature physically and mentally, and have poor self-judgment. The environment will have a greater impact on them. In the middle school English classroom, teachers have their class in English, which will make students under the influence of English environment, thus enhancing their sense of English and the like. Make full use of all available teaching methods to create a cultural and linguistic environment (Zhao, 2009). After at least four years learning of English in primary school, junior high school students have theoretically reached the second level of language skills stipulated in the new curriculum standards. In listening and speaking ability, they can understand simple questions in classroom activities, make short narratives on daily topics, and make clear pronunciation in oral expression. Although students' vocabulary is limited, teachers can issue classroom instructions in English which is popular and easy to understand according to their actual situation. Most of the teachers we interviewed also indicated that the students of the grade 7 of junior high school may not be well adapted to such an English environment at first, but they can understand some simple and common questions. Teachers can also train students' thinking in English by asking questions in English without fixing their minds in mother tongue.

In the classroom, Chinese can be used as an auxiliary language to help students learn English better. Therefore, teachers should pay attention to their own expression, tend to English as much as possible, and create a good classroom atmosphere. In the new curriculum standard, English teachers are required to organize their teaching in English and to use as little or no mother tongue as possible.

4) Enriching the forms of classroom activities and improve students' enthusiasm and initiative in learning. The way teachers employ in class will affect students. So it is very primary for teachers to choose the appropriate one to apply. Teachers should know as a second language, students' acceptance of English is not as good as that of their mother tongue. The responsibility of English teachers is to instruct students how to learn English well. Teachers, in the teaching process, not only let students input knowledge, but also let students output the knowledge to apply to all aspects of life and learning. In listening and speaking ability, students should get a basic level. Therefore, teachers should optimize classroom activities and enhance students' learning enthusiasm. But most teachers say that the main place for students to 
learn oral English is the classroom, but only by asking questions, 40 minutes in a class, and 40 students in a classroom. There is no enough time for each student to respond to the questions and practice. Therefore, other activities in class are also very critical for students' oral training. For example, teachers can use pair work, group discussion, role-playing, etc. to strengthen the dialogue practice between students, so as to promote the English communication between students and students, thereby improving the spoken English.

Situational teaching method can make students understand and quote some abstract and complex English knowledge more intuitively and vividly, and then can effectively improve their English (Jin, 2017). In addition, teachers can also integrate situational teaching method into classroom teaching more. The content of English textbooks in junior high school is close to everyday life. Teachers can create certain situations in the classroom so that students can understand them better.

5) Enriching English extracurricular activities to make students enjoy learning. Teachers can arrange some extracurricular activities which can promote students' oral expression ability, so that students can enjoy learning and improve themselves in the activities. Because junior high school students are in a critical period of physical and mental development, they are pretty active. And they have more time to do extra-curricular activities. Teachers can organize and carry out some extracurricular activities related to English, such as English corner, English drama performance, speech and so forth. In the activities, teachers can let students choose the theme of each activity according to their interests, so that students can participate in activities fully.

6) Strengthening the connection between home and school to promote the improvement of students' listening and speaking ability. In addition to some private secondary schools, public secondary schools are generally not enrolled, so students spend much time at home. But the self-control of junior high school students is not so strong, so parents need to play their role. Teachers can advise parents to accompany their children in oral training. Even if parents don't know spoken English, they will also make their children possess a learning state. In addition, parents can also cultivate their children's English thinking ability. For example, when they go out to the supermarket, they can randomly test the English sayings of their children's items. The main reason is to see if their children are quick in thinking.

7) Strengthening training based on network technology. Now it is an information age, the application of network technology is very extensive, and the development of man-machine dialogue is also based on network information technology. Therefore, teachers can arrange more online training for students to adapt to this model. At present, most middle schools in Zhejiang Province have introduced human-computer interaction system to train students' spoken language. However, some teachers say that the training time in schools is limited. In the case of a large number of classes and fewer laboratories, there are few opportunities for each student to go to the laboratory for training, so they still need to rely on classroom or after-school homework. Schools can adopt an App for students to practice.

In order to avoid the situation mentioned above that students do not complete their homework. Teachers should consider the actual situation in which students complete their homework. They should give students appropriate oral homework, such as half an hour of oral homework every day. Teachers should not neglect teaching links of spot checks in class and on-the-spot guidance (Pei, 2014). While students use App to test after class, teachers should seriously check the completion of students and the quality of completion in time, and give students some feedback. It is convenient for students to correct later. This is conducive to students to develop a good habit of learning, and effectively promoting oral English and all aspects of learning.

Moreover, Apps on many mobile terminals can also train oral English. Students can practise oral English on Apps too. Software on mobile can give scores and correct them. This is an effective way to promote students' listening and speaking ability.

\section{CONCLUSION}

Above all, man-machine dialogue can be said to be an inevitable trend in the reform of the current secondary school entrance examination, as well as a symbol of the information age. As we know, listening, speaking, reading and writing are very important in language learning. In today's society, the phenomenon of "dumb English" among students in various schools is quite serious, which shows that students' ability of listening and speaking in English is relatively weak. This is caused by the long-term emphasis on written form and neglect listening and speaking ability. Listening and speaking ability is a skill that students must master. In the long run, it is beneficial to students' life-long learning, because it requires students to speak scientifically, fluently, accurately and authentically. It has a great impact on students and teachers. It requires students to practice and test simultaneously. The improvement of students' ability is rooted in the classroom, which is the first, and a series of extracurricular activities are the extension of the classroom. In any case, teachers play an important role in it. Both teachers and students should improve themselves to adapt to this era.

\section{REFERENCES}

[1] Chen Jingdi. (2019). Problems and Countermeasures of Oral English in Junior High School. Course Education Research, 14,126.

[2] Chen Weiwei. (2016). Innovative teaching reform of interactive teaching for dumb English. New curriculum, 6, 22.

[3] Chen Ning. (2009). An Analysis of the Concept and Characteristics of Oral English Teaching. China Science and Technology 
Information, 14, 225-226.

[4] Jin Jian'an. (2017). The Application of situational teaching mode in junior high school English teaching. English on Campus, 43, 125-126.

[5] Pei Bei. (2014). A Brief Analysis of Man-machine Dialogue and Oral English Teaching in Junior Middle School. Intelligence, 36, 97.

[6] Sopian Saupi Irawan. (2019). English Teacher's Methodological Competence in Implementing Communicative Language Teaching in Teaching Speaking. Atlantis Press, Vol. 253, No.3, 518-521.

[7] Wang Ying. (2018). Training Strategies of Middle School Students' English Listening Ability in the Context of Man-Machine Dialogue. Teaching Research for Primary and Middle Schools, 1, 76-79.

[8] Xu Zhuo. (2017). On the phenomenon and Countermeasures of students' dumb English in middle school English Teaching. Read and Write Periodical, 11, 89.

[9] Yu Liping. (2018). Practical Exploration on the Teaching Strategy of Man-machine Dialogue Listening and Speaking in Senior High School Entrance Examination. English Teachers, 15,113-115.

[10] Zhao Yongping. (2009). A Study of Foreign Language Learning from the Phenomenon of Dumb English. The Science Education Article Collects, 1, 154-155.

Jiani Yao was born in jiaxing, P.R. China in 1998. She is currently a college student in Zhejiang Ocean University, majoring in English Teaching. Her research interests include teaching and language.

Fusheng Zhang, born in P.R. China in 1981. He is currently a lecturer of Foreign Language College, Zhejiang Ocean University.

Hongying Li, born in Born in Hubei, P.R. China in 1968. M.A in English Discipline Pedagogy at Institute of Foreign Languages of Huazhong Normal University in 2003.

She is currently an Associate Professor of Foreign Language College, Zhejiang Ocean University. Her relevant research and core viewpoints mainly focus on the construction of classroom teaching models, the interpretation of classroom texts and the study of classroom discourse, the study of classroom teaching strategies. 